\title{
Museum science?
}

\section{KERSTIN SMEDS}

"If anyone talked or wrote about museology as a science thirty or twenty years ago, he would be met with a pitying, disdainful smile from many persons. Today, the situation is quite different."

This statement sounds familiar to us museologists, doesn't it? It is a statement on museology in an article named "Die Museologie als Fachwissenschaft" (Museology as a branch science), written by a renowned German scholar. Nothing special there, only the fact that he wrote it more than 130 years ago (Grässe 1883). Today, one may ask, is the situation any different? Certainly, things have happened. Museology has developed, Museum Studies has conquered the world, Critical Heritage Studies has seen the light of day. Nevertheless, in many countries and under different circumstances, museology is still questioned, not the least among museum professionals themselves.

The question whether museology is a "science" or not is not solved and will perhaps never be. One may also ask if this is important when it comes to what kind of research that is carried out in this field, and how? In my opinion, not so much. Regardless of the arguments in favor of or against museology as a science, it is a very healthy branch, growing fast. Museology is certainly a "science" and a discipline in its own right. After all, most other cultural fields has developed its "own" scholarly discipline - such as archival and library sciences, media sciences, film science, theatre studies, literature science (studies) musicology and so on, and nobody seems to question whether these are "sciences" or not. So why this fuss about museology (in Sweden)?

If one wants to distinguish museology from Museum Studies, as many are inclined to, I would say that museology is characterized by a more theoretical approach often operating on a meta-level of thought and analysis. One of the pioneers of the new, theoretical museology of the 1970s was Anna Gregorová, who (1980:20) distinguished three domains worthy of studying:

a. The museum's relation to reality and time (existential and semiotic dimension)

b. The museum's relation to society (political and cultural political dimension)

c. The museum's practical functions (organization and mission)

Thus, museology belongs to the humanities and social sciences; it is a human-socialscientific discipline. The French sociologist and museologist Bernard Deloche went further and defined museology as our "relation spécifique" to reality. He deals with "musealité" with reference to communication and social interaction in a political and ideological sense. Museums (and heritage institutions, I would add) are processes with the aim of making man's multifaceted relation to time, reality and history visible. Museology, in turn, should reveal and explain how this is done. Deloche ends up stating that museology is a "philosophie du muséal" and, as such, a "metatheory", not a science. Thus, museology is "contractuelle", a corporate agreement on its objectives (Deloche 1999). 
My own view concurs very much with Deloche's approach. Moreover, museology of today should not be limited to the study of the museum phenomena solely, but the entire field of heritage and the ideology and practices of preservation. Pretty much in the same way as the "new" field of Critical Heritage Studies does. I would formulate my personal view in the following way: museology is a theoretical and philosophical platform for the study of industrial man's (traumatic) relationship to time and to the material world, and how this is expressed in musealization and preservation of reality, things, environments and "heritage" of all kinds. Museology is dealing with the concept of loss as an existential, philosophical and practical problem. Museology focuses on the problem of time in our culture, and on what strategies we draw to stop time, prevent deterioration, procrastinate entropy and, if only possible, to postpone death (Smeds, 2007).

Now, I would like to mention another aspect of museums and museology; the question of change. First, look at this:

The second step, if museums are going to become a dynamic force, must be the realization that the functions are not static either in their relationship to one another or in their importance. Both aspects change even as do the times. Thus, if the term "museum" is going to mean something in the future, museums of today must be willing to alter and to modify their internal structure and their ideas to fit the changing world conditions and the advances in social thought. Museums have failed to do this and have shown a most extraordinary reluctance to accept new social theories and new social ideas.

I have picked this quotation because it may represent a common critique of museums at any time during the last hundred years. The quote was written 75 years ago (Low 2004 (1942)).
As a museologist, I have always been very 155 interested in mechanisms that are slowing down or even preventing change. Ever since their birth, museums have been criticized for being inflexible, dusty and old-fashioned. Museums should change, become more accessible, and so on, and this talk is going on and on, no matter what museums do. I have been asking myself, why this is the case? One hypothesis is that there are paradigmatic reasons and obstacles for any deeper acknowledge of real change. Reasons that are hidden within the museum itself - that is in the fact that departments of collections and those of communication and exhibitions most often work according to entirely different paradigms and traditions. This often "silent knowledge" of how things should be done is imbedded in the minds of staff. The paradigmatic conflict consists of a gap between positivism, taxonomy and the idea of eternal preservation on the one hand, and accessibility, hermeneutics, phenomenology and the idea of a creative and allowing relationship with our material heritage on the other. This is one crucial question for museology to study; logical gaps, processes of change and resistance to change. The way to bridge the gap is to see the museum not as an institution, but as a processes, in a state of constant change (Smeds 2016).

As for the future of museology, and how it could be useful for the field of museums and heritage, I want to stress the importance of social museology or sociomuseology. We should dust off this interesting branch of museology under the umbrella of MINOM, Mouvement international pour une nouvelle Muséologie. MINOM is an Affiliated Organization of ICOM, created in 1985 and of growing importance. From the beginning, MINOM has been a prime network of people working in community museums, ecomuseums, local museums and other types of museums that use methodologies 
with a strong grassroots and community emphasis, often referred to as new museology.

The philosophy and agenda of MINOM is expressed in their Rio Declaration:

By valuing collective and participative work, MINOM has been considering museums as strategic devices for the defence of social dignity, citizenship and the right to creativity and memory. The mission of a museums should be to improve quality of life and generate benefits for the local community and for the city as a whole, dealing with important issues on a universal scale, such as fighting racism and various forms of violence, enabling environmental preservation and ensuring accessibility to education and professional training. (Chagas, Assunção dos Santos \& Glas 2014).

Some of these contemporary issues may be expressed in the following "sociomuseological" questions: How can public cultural policy ensure commitment to systematic and continuous investment in community-based and popular memory initiatives and museological processes? How can social museums be provided with the museological tools, languages and methods that are most convenient for them? How can visibility and institutionalized processes be increased without reducing the autonomy and the social capacity of popular and communitybased memory initiatives and museological processes? These questions also serve as a basis for the ongoing, large European research project SoMus: Study on Cultural participation in European Local Museums (SoMus home page). This project seems, in my view, to hit the nail when it comes to museological relevance today! The most important task for museology is to provide analytical and practical tools for the field of museums and heritage to use in their development of both socially and economically sustainable activities and institutions.

\section{INTERNET SOURCES}

SoMus home page: http://www.ces.uc.pt/projectos/somus/index.php?id=12419did_lingu$a=1$ \&pag $=12420$

\section{LITERATURE}

Chagas, Mario, Paula Assunção dos Santos \& Tamara Glas 2014. "Sociomuseology in Movement: MINOM Rio Declaration." Museum International 64, 99-106. https://doi.org/10.1111/muse.12025

Deloche, Bernard 1999. "Museologie et philosophie." In Hildegard Vieregg (ed.). Museology and Philosophy. ICOFOM Study Series 31. München: Museums-Pädagoisches Zentrum, 8-17.

Gregorová, Anna 1980. Text forming part of a section titled "Museology - Science or just Practical Museum Work?". MuWoP (Museological Working papers) $\mathrm{nr}$ 1. Stockholm.

Grässe, Johann, G. T. 1883. "Die Museologie als Fachwissenschaft." Zeitschrift für Museologie und Antiquitätenkunde.

Low, Theodore 2004 (1942). "What Is a Museum?." In Gail Anderson (ed.). Reinventing the Museum. Historical and Contemporary Perspectives on the Paradigm Shift. Lanham, New York, Toronto \& Oxford: Altamira Press, 30-43.

Smeds, Kerstin, 2007. "Vad är museologi??" RIG, Etnologisk Tidskrift, 2.

Smeds, Kerstin, 2016. "Here Comes Everybody - The Visitor Business in Light of Existential Philosophy." In Ann Davis \& Kerstin Smeds (eds.). Visiting the Visitor - Enquiries into the Visitor Business in Museums. Bielefeld: Transcript Verlag, 105-126.

\author{
Kerstin Smeds, Professor of Museology \\ kerstin.smeds@umu.se
}

Institutionen för kultur- och medievetenskaper Umeå universitet

S-901 87 Umeå, Sweden 